\title{
Application of Model Cooperative Learning Group Investigation against Student Learning Outcomes on Course Introduction to Accounting
}

\author{
Putri Kemala Dewi Lubis ${ }^{1}$ \\ \{putrikemaladewilubis.unimed@gmail.com ${ }^{1}$ \} \\ Department of Economics, Medan State University, Medan, Indonesia ${ }^{1}$
}

\begin{abstract}
This research aims to look at the effect of an Increase in student learning outcomes in the course Introduction to Accounting Prodi Economic Education first half of the school year 2018/2019 by applying cooperative learning models of Group Investigation (GI). This research is a classroom action research (PTK). The subjects were students Prodi Economic Education first half of the school year 2018/2019. This research was conducted in two cycles with four stages of implementation: planning, implementation, observation, and reflection. This research techniques of data collection are observation and questionnaires. The instrument of this research is the observation sheets and questionnaires.The results of this study indicate that Learning Activities Introduction to Accounting increase is after given action. The Increase in the percentage of students in Accounting Learning Activities based on observations of the first cycle is $68 \%$ to $88 \%$ in the second cycle. The Increase in the percentage of students in Accounting Learning Activities based on questionnaires of the first cycle is $83 \%$ to $93 \%$ in the second cycle. Accounting Student Achievement Learning Activities individually by category Very High and High based on observations was $55 \%$ in the first cycle Increased to $85 \%$ in the second cycle. Achievement of Learning Activity Accounting student individually by category Very High and High-based questionnaire was $92 \%$ in the first cycle Increased to $98 \%$ in the second cycle.
\end{abstract}

Keywords: Cooperative learning is a model of Group Investigation (GI); Learning outcomes; Introduction of accounting 


\section{Introduction}

During this lack of analytical skills of students in terms of learning outcomes of students in the course Introduction to Accounting more due to the approach, methods or strategies which are used by professors in the learning process is still traditional and less to allow students to develop thought patterns in accordance with their abilities -masing. Alternative solutions to address the problem of accounting student learning activity that is less than optimal is to apply the model of learning that stimulates the growth of activity. The learning model that can be applied is cooperative learning. Cooperative learning model is a model of learning by groups. According Miftahul Huda (2012: 33) in cooperative learning, students should be active participants and through the group can build learning communities help each other. Learning like this requires more active among students to work together to achieve group goals, to train students in expressing their opinions or ask questions, and carry out the tasks which it is responsible within the group.

Cooperative learning model that can be selected to address the problem of lack of classroom learning activities accounting in the first half Prodi Ekonomia Education dalah type Group Investigation (GI). According Miftahul Huda (2012: 124), the Group Investigation (GI) Students will be involved in activities such as making a summary, hypotheses, conclusions, and present a final report. Implementation of cooperative learning modelGroup Investigation (GI) in general is a lecturer in designing a fairly broad scope of topics and then divide it into sub-topics.

Implementation Group Investigation (GI) in the study is expected to improve student learning activities. Group Investigation (GI) require students to actively seek information from various sources, so that students not only rely on the lecturer as an information resource. Through Group Investigation (GI) Students are expected to be more active, namely in terms of recorded material, cooperation within the group, issued an opinion / ask, answer questions, participation in preparing reports and presentations, as well as enthusiastic about learning.

\subsection{Formulation of the Problem}

Based on the background that has been described above, the problem in this research is how to increase student learning outcomes by implementing cooperative learning model investigation group (Group Investigation) introductory accounting courses in the first semester of the academic year students of 2018/2019?

\subsection{Research Purposes}

Based on the formulation of the problem, so the research objectives to be achieved through this research is to analyze the improvement of student learning outcomes by implementing cooperative learning model investigation group (Group Investigation) on introductory accounting courses at the department of Economic Education.

\section{Theoretical Study}

\subsection{Type Group Investigation}


Model Group Investigation by Slavin (2005: 216) is a cooperative planning students on what is required of them. Members of the group take part in the planning of various dimensions and demands of their projects. Cooperative planning skills should be introduced gradually into the classroom and trained in a variety of situations before the class is carrying out a full investigation project ". It is intended that the Group Investigation will be successfully carried out if each member of the group participate actively participated from the beginning of the end sampatactivities, namely in terms of planning, investigation, preparation of a report or presentation of the results of investigations should be done to be able to run smoothly.

\subsection{Learning Outcomes}

Nana Sudjana (2009: 3) defines student learning outcomes in is a change in behavior as a result of learning in a broader sense include the areas of cognitive, affective, and psychomotor. Learning Outcomes are the abilities of the students after receiving their learning experience. "From these processes will lead to new experiences by students. The realization of his own learning outcomes are skills that have been mastered by students, so that the learning outcomes is the ability of students receiving learning experience which looked at changes in behavior.

\section{$3 \quad$ Framework Of Thinking}

This study uses cooperative learning Group Investigation. Implementation of cooperative learning model of Group Investigation in general is a lecturer in designing a pretty broad scope of topics and then divide it into sub-topics. The class is divided into groups of 5-6 students. These groups can be formed based on shared interests, or familiarity. Students are given the freedom to form their own group. Each group chooses a topic and then conduct an investigation on the topic. As part of the investigation, students seeking information from various sources that offer a variety of ideas, opinions, data or solutions related to the topic being studied. Results of investigation of students then made a report and presented to the class. Lecturer in this study serve as resource persons and facilitators. Based on the above, frameworks can be described as follows:

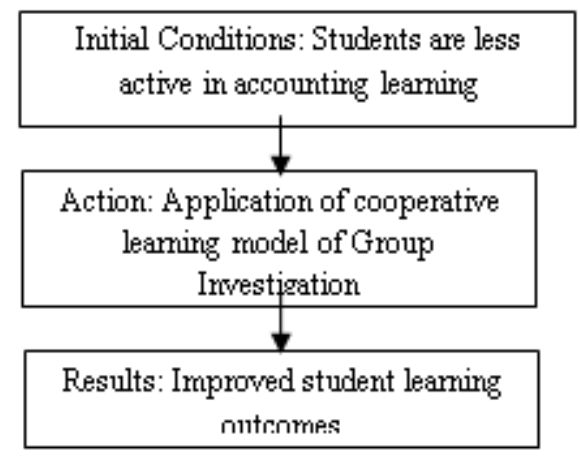

Fig. 1. Frame of work 


\section{Research Methods}

The method used in this research is descriptive qualitative technique Classroom Action Research (CAR), which was adapted from the model Kemmis and Taggart (1998). According to Stephen Chemish (in D.Hopkins, 1993, p. 44) action research is a form of reflective study by the perpetrators of the measures taken to increase the stability of the rational faculty of action in implementing the tasks, deepen understanding of the measures for what he does, and improving the conditions in which these learning practices do (Suryana, 2010: 43). The study consisted of a cycle of the cycle from planning, implementation, monitoring, and reflection does that aims to improve the learning process.

\subsection{Operational Definition of Variables}

- Cooperative Learning Model Group Investigation is one type of cooperative learning model. The class is divided into groups of 5-6 students. Students are given the freedom to form a group. Each group chooses a topic and then conduct an investigation on the topic. As part of the investigation, students seeking information from various sources that offer a variety of ideas, opinions, data or solutions related to the topic being studied

- Learning outcomes :The results of this study is to learn in introductory accounting learning outcomes obtained by the students after a group investigation methods applied in the form of a written test where the ability were measured students' cognitive abilities such as knowledge (C1), comprehension (C2), and application (C3).

\subsection{Data Analysis Techniques}

This research uses descriptive quantitative data analysis techniques. Data analysis was performed to analyze the Accounting Learning Activity data obtained from the results of observation and questionnaires. The data analysis was conducted at the end of the cycle, so it can be an increase or not.

\section{Results And Discussion}

The success of these measures can be seen from the observations of the learning process. If the results obtained are in accordance with the success criteria predetermined action then this action is declared successful.

Based on the above table can be seen in the improvement of learning outcomes Introduction to Accounting as a whole from the first cycle to the second cycle. Accounting Learning Outcomes percentage in the first cycle showed a $68 \%$. This means Learning Outcomes Introduction to Accounting in the first cycle is not as expected. Learning Outcomes Introduction to Accounting in the second cycle shows the figure of $88 \%$. This shows an increase in the percentage of Learning Outcomes Introduction to Accounting from the first cycle to the second cycle of $20 \%$. Percentage of Learning Outcomes Introduction to Accounting in the second cycle have achieved the expected results of more than $75 \%$. 
Table 1. Improved student learning outcomes based on observations in the first cycle

\begin{tabular}{cccc}
\hline No. & $\begin{array}{c}\text { Learning Activity Indicator } \\
\text { Accounting }\end{array}$ & Cycle I & Cycle II \\
\hline 1 & record material & $65 \%$ & $85 \%$ \\
2 & Cooperation within the group & $75 \%$ & $95 \%$ \\
3 & Issuing opinions / ask & $50 \%$ & $80 \%$ \\
4 & Answer the question & $60 \%$ & $85 \%$ \\
5 & Participation in the making report and & $90 \%$ & $95 \%$ \\
& presentation & & $\mathbf{8 8 \%}$ \\
\hline
\end{tabular}

Table 2. Improved student learning outcomes based on observations on the second cycle

\begin{tabular}{cccc}
\hline No. & $\begin{array}{c}\text { Learning Activity Indicator } \\
\text { Accounting }\end{array}$ & Cycle I & Cycle II \\
\hline 1 & record material & $75 \%$ & $90 \%$ \\
2 & Cooperation within the group & $100 \%$ & $100 \%$ \\
3 & Issuing opinions / ask & $65 \%$ & $75 \%$ \\
4 & Answer the question & $75 \%$ & $90 \%$ \\
5 & Participation in the making report and & $95 \%$ & $100 \%$ \\
& presentation & $85 \%$ & $98 \%$ \\
6 & Enthusiastic about learning & $\mathbf{8 3 \%}$ & $\mathbf{9 3 \%}$ \\
\hline
\end{tabular}

Based on the table above shows an increase of Learning Outcomes Introduction to Accounting as a whole from the first cycle to the second cycle. The first cycle indicates the percentage of Learning Outcomes Introduction to Accounting for $83 \%$, while in the second cycle of $93 \%$. This shows an increase of Learning Outcomes Introduction to Accounting for $10 \%$.

Learning Outcome Indicators Introduction to Accounting in the questionnaire coupled with indicators that can not be observed directly by observation. The indicator is enthusiastic about learning. According to the table above, the percentage of indicators enthusiastic about learning as much as $85 \%$ in the first cycle increased to $98 \%$ in the second cycle. This shows that students have a high enthusiasm in the implementation of cooperative learning model of Group Investigation (GI).

Improved Learning Outcomes Accounting for results obtained from the observations and the results of questionnaires. One indicator of Learning Activity Accounting achieve a satisfactory result is an indicator of cooperation within the group. Indicators Activities Learning Accounting else also increased with the implementation of Cooperative Learning Model Group Investigation (GI). Cooperative learning has positive consequences that the students are given the freedom to be actively involved in their group. Pertisipan students must be active and help each other (Miftahul Huda, 2012: 33). Thus the implementation of cooperative learning model is indeed appropriate to improve student learning outcomes Introduction to Accounting Economic Education Semester I. 
Improved Learning Outcomes Introduction to Accounting percentage of students overall based on observations of the first cycle is $68 \%$ to $88 \%$ in the second cycle. Indicators record material increased from $65 \%$ in the first cycle to $85 \%$ in the second cycle. Indicators of cooperation within the group increased from $75 \%$ in the first cycle to $95 \%$ in the second cycle. Indicators of expression / ask increase of 50\% in the first cycle to $80 \%$ in the second cycle. Indicators answered questions increased from $60 \%$ in the first cycle to $85 \%$ in the second cycle. Indicators of participation in preparing reports and presentations by $90 \%$ in the first cycle increased to $95 \%$ in the second cycle.

Improved Learning Outcomes Introduction to Accounting percentage of students overall based on questionnaires of the first cycle is $83 \%$ to $93 \%$ in the second cycle. Indicators record material increased from $75 \%$ in the first cycle to $90 \%$ in the second cycle. Indicators of cooperation within the group remained at $100 \%$ in cycle I and II. Indicators of expression / ask increase of $65 \%$ in the first cycle to $75 \%$ in the second cycle. Indicators answered questions increased from $75 \%$ in the first cycle to $90 \%$ in the second cycle. Indicators of participation in preparing reports and presentations by $95 \%$ in the first cycle increased to $100 \%$ in the second cycle. Indicators enthusiastic about learning increases of $85 \%$ in the first cycle to $98 \%$ in the second cycle.

\section{References}

[1] Dimyati \& Mudjiono. Teaching and Learning. Jakarta: Rineka Reserved. (2009).

[2] E. Mulyasa. Competency-Based Curriculum Concepts, Characteristics, Implementation, and Innovation. Bandung: Youth Rosdakarya. (2006).

[3] Eko Putro Widoyoko. Evaluation of Learning Program A Practical Guide For Prospective Teachers and Educators. Yogyakarta: Student Library. (2009).

[4] Khusnul khotimah. Application of Cooperative Learning Model Group Investigation in Improving Student Learning Activities Class X Accounting Expertise Program SMK 1 Bantul Year 2009/2010. Essay. UNY. (2009).

[5] Martinis Yamin. Students membelajarkan tips. Jakarta: Echoes Press Persada Jakarta. (2007).

[6] Masnur Muslich. PTK implement it Easy (Classroom Action Research). Jakarta: Earth Literacy. (2011).

[7] Miftahul Huda. Cooperative Learning Methods, Mechanical, Structural and Implementation Model. Yogyakarta: Student Library. (2012).

[8] Oemar Hamalik. Curriculum and Learning. Jakarta: Earth Literacy. (2011).

[9] Radno Harsanto. Dynamic Classroom Management. Yogyakarta: Canisius. (2007).

[10] Rianti Sri Sulistia Infantry. Implementation Method Investigation Cooperative Group mode to Improve Civics Activities and Student Achievement SMA Negeri 2 Wonosari. Essay. UNY. (2009).

[11] Rochiati Wiriaatmadja. Class Action Research Methods. Bandung: Youth Rosdakarya. (2009).

[12] Sardiman. Interaction \& Learning Motivation. Jakarta: Rajawali Pers. (2011).

[13] Slavin, Robert. ECooperative Learning Theory, Research and Practice. Bandung: Nusa Media. .(2010).

[14] Sugiyono. Educational Research Methods Quantitative Approach, Qualitative and R \& D. Bandung: Alfabeta. (2009).

[15] Suharsimi Arikunto, Suhardjono, and Supardi. Classroom action research. Jakarta: Earth Literacy. (2009).

[16] Trianto. Designing Innovative Learning Model Progressive Concepts, Policy, and Implementation in Education Unit Level Curriculum (SBC). Jakarta: Kencana Prenada Media Group. (2010). 